\title{
Public Expenditure and Economic Growth in Sri Lanka: Cointegration Analysis and Causality Testing
}

\author{
W A Dilrukshini ${ }^{1}$
}

\begin{abstract}
The purpose of this study is to analyze the relationship between public expenditure and economic growth in Sri Lanka during 1952-2002. The study tests the validity of Wagner's Law that there is a long-run tendency for public expenditure to grow relative to national income. This implies that public expenditure can be treated as an endogenous factor, not a cause of growth in national income. In contrast, Keynesian hypothesis treats public expenditure as an exogenous factor. In former approach, the causality runs from national income to the public expenditure while in the latter approach causality runs from public expenditure to national income. The study finds no empirical support either for the Wagner's Law or the Keynesian hypothesis, in the case of Sri Lanka. (JEL H10, C52)
\end{abstract}

\section{Introduction}

There are two propositions on the relationship between public sector expenditure and national income. These two propositions are Wagner's law and Keynesian hypothesis. According to Wagner (1883) when the economic activity grows there is a tendency for the government activities to increase in long-run. According to Keynesian hypothesis, government spending is an exogenous policy instrument that cause changes in aggregate level of real output in the short-run.

The majority of empirical analyses of the impact of government expenditure on long-run economic growth used cross-section analysis (Abizadeh and Gray 1985, Chen et al 2003, AlFaris 2002, Ram 1986a, 1986b). The most common results highlight that government expenditure is detrimental to economic growth. However, the cross-country growth regressions do not capture the dynamics of the relationship between these two variables and disregard country-specific factors. Therefore, as Henrekson (1992) states, a test of Wagner's Law should focus on the time-series behavior of public expenditure in a country for as long a time period as possible, rather than on a cross-section of countries at different income levels. Another shortcoming of these studies is that those researchers interpreted a significant coefficient of the measure of government expenditure as a confirmation of causality from government spending to economic growth (only the Keynesian view), but this equation can be equally compatible with the Keynesian view or with Wagner's law (causality from growth

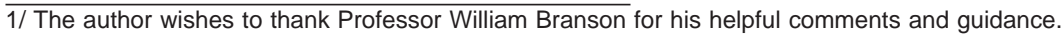


to government expenditure) as well as a bi-directional causality between the two variables. Typical growth regressions provide no insights into the direction of causality, but rather focus on relationship between these two variables. Recently some empirical studies have begun testing for the bi-directional causality by using time-series data, but focused mainly on developed countries. Little attention has been taken in the empirical analyses on the testing for the bi-directional causality between government expenditure and economic growth with respect to developing countries. In the Sri Lankan context there is no study, which analyzes the Wagner's Law using the standard econometrics techniques of cointegration and causality.

The remaining part of the paper has the following sections. Section II explains Wagner's Law and the Keynesian hypothesis. Section III discusses the recent empirical studies in other countries. Section IV presents the analytical frameworks for the study. Section V explains data. Section VI examines the public expenditure pattern of Sri Lanka. In section VII, the methodology is discussed. The empirical results derived from estimation are covered in section VIII. Finally, section IX provides some conclusions.

\section{Theory}

Wagner's Law, which is also called as 'the Law of Rising Public Expenditure', states that growth in economic activity causes an increase in government activities, which in turn raises public expenditure. The Law postulates that (i) an increase in national income of a country leads to a growth in public expenditure; (ii) the extension of the functions of the state leads to an increase in public expenditure on administration and regulation of the economy; and (iii) the rise in public expenditure will be more than proportional to the increase in the national income and will thus result in a relative expansion of the public sector. Wagner's Law basically examines the long-term trends in public expenditure and economic growth, where economic growth leads to greater public sector expansion.

Wagner further recognized three functions of the government:

i. Providing administration and protection;

ii. Ensuring stability; and

iii. Providing for the economic and social welfare of society as a whole

According to Wagner, public expenditure on the first of these would grow because the increasing division of labor would lead to the breakdown of mutual relationships, requiring the state to take over functions previously carried out by families and local communities. In this way, public administration would become more centralized and administrative units larger. Moreover, Wagner assumed that private sector monopolies would not adequately take into account the social needs of society as a whole and would therefore need to be replaced by public corporations. He further assumed that if private sector companies became larger and larger, the economy would become unstable because problems for individual companies would become problems for society as a whole. Finally, government would need to expand to provide for the economic and social welfare of society as a whole such as education and health care, which Wagner saw as not open to economic evaluation.

A number of time series empirical studies have in the past found support for Wagner's law. These, however, might not be reliable because they did not employ cointegration tests 
to establish stationarity in the relevant variables. (see for example, Beck 1982, Bird 1971, and Peacock and Wiseman 1979).

In contrast to Wagner's law there is another approach, which is associated with Keynesian macroeconomic models. According to Keynes public expenditure is seen as an exogenous factor, which can be used as a policy instrument. In traditional Keynesian theory, fiscal policy is an important tool for manipulation of short-run demand.

\section{Experience from Other Countries}

The relationship between public expenditure and national income has long been discussed by public finance scholars and macroeconomists. As noted above, while public finance studies have generally hypothesized that growth in government expenditure is caused by growth in national income (Wagnerian approach), macroeconomic models have examined the opposite direction (Keynesian approach). Accordingly, while public finance studies have considered public expenditure as a behavioral variable, Keynesian models have treated public expenditure as an exogenous policy instrument designed to correct short-term cyclical fluctuations in aggregate expenditure. In a recent review article Agell et al (1997) claim that theoretical and empirical evidence does not allow any conclusion on whether there is a relationship between the rate of economic growth and the size of the public sector in terms of public expenditure. The major shortcoming of their conclusion is that they base their conclusion on empirical studies, and on their own classical regressions, without evaluating the econometric problems that arise. Many early studies on Wagner's law ignored the stationarity requirement of time-series variables. The assumption of the classical regression model require that time series variables be stationary and that errors have a zero mean and finite variance. In the presence of non-stationary variables, there might be what Granger and Newbold (1974) called a spurious regression, whereby the results obtained suggest that there are statistically significant relationships between variables in the regression model when in fact all that is obtained is evidence of contemporaneous correlation rather than meaningful causal relations ${ }^{2}$. Hence, before conducting causality tests, variables must be found to be stationary individually or if both are non-stationary, they must be cointegrated.

Researchers have applied causality testing techniques to evaluate the two different approaches (i.e. Wagner's Law and Keynesian hypothesis). In public finance, the causal link between public expenditure and national income was first examined by Singh and Sahni (1984) and Sahni and Singh (1984) using annual data for Canada and India respectively. Since then, causality studies of such nature have had a central place in modern public expenditure analysis (Ansari et al 1997, Chengand Lai 1997, Demirbas 1999, Ghali 1997, Hondroyiannis and Papapetrou 1995, Khan 1990, Khundrakpam 2001). Those empirical studies produced mixed results; unidirectional causality from expenditure to income, or a bidirectional causality between two variables or no causal relationship. For example, Ram (1986a) for 63 countries found limited support to government sector expenditure rising with growth in national income. On the other hand, Abizadeh and Gray (1985) for 55 countries found support

2/ A spurious regression occurs where there is no relationship between variables in their joint generation, but we wrongly conclude from a regression analysis that there is such a relationship. A cointegrating regression is not a spurious regression. 
for a rise in the share of government sector in national income in the case of rich countries but not for poor countries. Chen et al (2003) using data from 6 developed countries (Canada, France, Germany, Italy, UK, and USA) and 3 developing countries (Korea, Singapore and Taiwan) during 1972 to 1992 conducted regression analyses with the proportion of public expenditure to GDP and economic growth rate. They found that economic growth rates declined along with increases of the proportion of public expenditure to GDP. Al-Faris (2002) examined the nature of the relationship between government expenditure and economic growth in the Gulf Cooperation Council countries. In his study, Al-Faris (2002) found that national income is a predictive factor of the expanding role of government as postulated by Wagner. His empirical investigations do not support the Keynesian hypothesis.

If one takes into consideration, country specific studies, Courakis et al (1993) for Greece and Portugal, Gyles (1991) for the UK, Peacock and Wiseman (1961) for the UK and some others provide support to rising share of government sector expenditure with the growth of national income, while Hondroyiannis and Papaperou (1995) for Mexico and Demirbas (1999) for Turkey find no evidence of any long-run relationship between government sector expenditure and national income. Cheng and Lai (1997) for South Korea, examining the causality between public expenditure and economic growth along with money supply for the period of 1954-1994, found that there is a bidirectional causality between public expenditure and economic growth in South Korea. Ghali (1997) analyzed the relationship between government expenditure and economic growth in Saudi Arabia by examining the intertemporal interactions among the growth rate in per capita real GNP and the share of government spending in national income. Ghali found no consistent evidence that government spending can increase Saudi Arabia's per capita output growth. He found the flow of causality running in the other direction, which supports the Wagner's hypothesis.

Hansson and Henrekson (1994) find that government consumption spending is growthretarding but spending on education impacts positively on growth. Kneller et al (1998) found that productive spending has a positive, while non-productive spending has a negative impact on growth of OECD countries. Ram (1986b), using a sample of 115 countries, found government expenditure to have significant positive externality effects on growth particularly in the developing countries sample, but total government spending had a negative effect on growth in the developing countries. Lin (1994), in contrast, found that nonproductive spending had no effect on growth in the advanced countries but a positive impact in LDCs.

As noted above, most of the empirical studies are cross-section, and specific country case studies are rare. Time series analysis for specific countries can avoid some of the econometric and sampling problems. Specifically, cross-section analysis assumes that the coefficients are the same for all countries in the sample whereas time series analysis can address country-specific features. A time series country study is potentially more informative, although the findings cannot be generalized to other countries. 


\section{Analytical Framework}

The theoretical relationship between public expenditure and economic growth is well-documented in the literature and therefore it will only be briefly discussed here. There are six broad versions of Wagner's Law, which define the relationship between economic growth and public expenditure. In all the six, some variant of the measure of national income explains alternate measures of public sector expenditure. The causation, however, could be in the reverse direction in each of these six models. There is no objective criterion to decide which of the six versions is the most suitable and convincing test of the Law. Therefore, we will need to consider and test all six versions of the Law. The six versions of the model are follows:

\begin{tabular}{|c|c|c|c|}
\hline & LTE & $=$ & $\mathrm{f}(\mathrm{LGNP})$ \\
\hline Il & LCE & 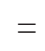 & $\mathrm{f}(\mathrm{LGNP})$ \\
\hline IIII. & LTE & 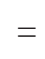 & $\mathrm{f}(\mathrm{L}(\mathrm{GNP}$ \\
\hline IV. & $\mathrm{L}(\mathrm{TE} / \mathrm{GNP})$ & - & $\mathrm{f}(\mathrm{L}(\mathrm{GNP}$ \\
\hline & $\mathrm{L}(\mathrm{TEN})$ & & $\mathrm{f}(\mathrm{L}(\mathrm{GN})$ \\
\hline & L(TE/GN & $=$ & $\mathrm{f}(\mathrm{LGNP})$ \\
\hline
\end{tabular}

where LTE is the logarithm of real total government expenditure, LCE is the logarithm of real government consumption expenditure, LGNP is the logarithm of real gross national product, $\mathrm{L}(\mathrm{GNPN})$ is the logarithm of per capita gross national product, $\mathrm{L}(\mathrm{TE} / \mathrm{GNP})$ is the logarithm of the ratio of real total government expenditure to real gross national product and $\mathrm{L}(\mathrm{TEN})$ is the logarithm of the per capita real total government expenditure.

The first version of the models, which is total public sector expenditure as a function of national income (GNP) was adopted by Peacock-Wiseman to test the Wagner's law. Pryor in 1968 developed the second version of the Law, which states that the consumption component of public sector expenditure increase with the rise in national income (see model II). Gofman (1968) and Mann (1980), however, define the law as increase in total public sector expenditure due to rise in per capita national income. That was the third version of the model (see model III). The fourth version of the model was tested by Murthy (1993) and Ram (1986a). The version indicates that growth in per capita income leads to rise in the share of total public sector expenditure in national income (see model IV). The fifth version of the model (see model V), which is per capita total public sector expenditure rising with per capita national income, was tested by Gupta (1967). Meanwhile, Mann (1980) defined the law as rise in the share of total public sector expenditure in the national income as a result of growth in national income (see model VI), and tested for validity of the law.

As mentioned above. the major shortcoming of the empirical studies on the Wagner's Law is that many of the studies were carried out without testing the properties of time series data for stationarity. Therefore, they lead suspicion to possible cases of spurious regression. To examine the stationary properties of the Sri Lankan data the cointegration test will be used. The investigation of stationarity (or non-stationarity) in a time series will find out by testing for unit roots. Existence of unit roots in a series denotes non-stationary. A number of alternative tests are available for testing whether series are stationarity. 
In order to establish the order of integration in the data set, Dickey Fuller (DF) and Augmented Dickey Fuller (ADF) tests will be employed. If a pair of I(1) variables are cointegrated, one then proceeds to build an error correction model (ECM) in order to capture the short-run and long-run causal relationship between the two series. As noted above, to eliminate methodological shortcoming of early studies, this study will employ cointegration analysis.

\section{Data}

Prior to presenting the empirical results, a word about the data is in order. The data consist of total public expenditure, public consumption and gross national product (GNP), all in real terms from 1952 to 2002. We use GNP because for developing countries, it is more appropriate to use GNP, which includes net factor payments (Mukherjee et al 1998). The data are also examined in per capita terms, and some categories of public expenditure are used in the form of ratios to GNP, as required by the various formulations of Wagner's Law.

\section{An Overview of Public Expenditure Pattern in Sri Lanka}

In Sri Lanka after regaining independence the successive governments have played a major role for well being of the public as well as for the economic development. Human development was considered as an important policy indicator and all the successive governments have invested more on public health and education. Eradication of poverty too was considered as one of the major tasks of the government. Hence successive governments were used to subsidizing poor segment of the society.

Government expenditure can be typically categorized into two components: recurrent expenditure and capital expenditure. Figure 1 shows the pattern of the government expenditure at constant prices. With the exception of year 1978, government recurrent expenditure exceeds capital expenditure. As shown in Figure 1, over the period of study, total govern-

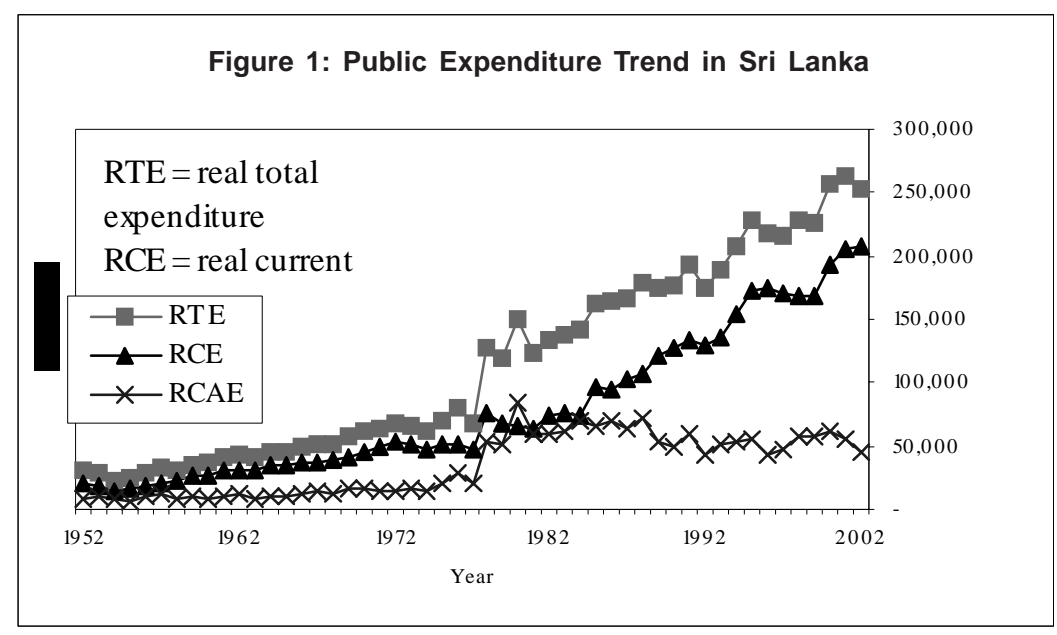



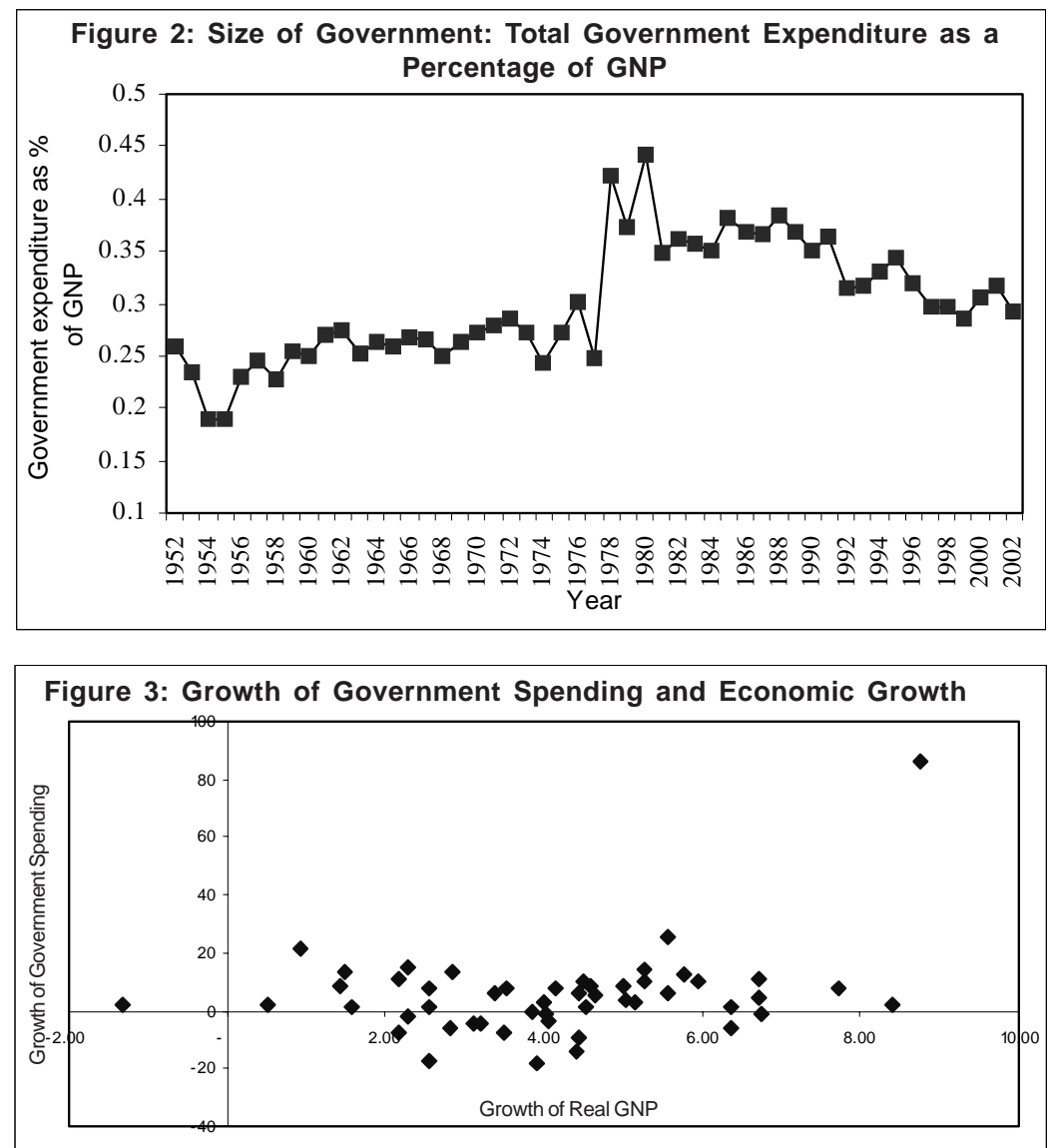

ment expenditure has increased while government recurrent expenditure has also increased about eightfold. The increase in public expenditure over the years, however, has not been consistent. The increasing trend of the government expenditure can be clearly divided into two phases: pre-liberalized period (before 1978) and post-liberalized era (after 1978).

A size of government in any country depends on several factors. However, in many countries, the size of government depends on political factors rather than market forces. Figure 2 shows the size of government in term of government expenditure as a percentage of GNP in Sri Lanka. Over the time period under consideration, the average government total expenditure as a percentage of GNP was 30 percent, which is relatively high compared to most other developing countries. In the pre-liberalized period, government expenditure averaged 25 percent of GNP, and increased to 35 percent of GNP in the post-liberalized era. There are two reasons for this trend. Government capital expenditures increased with the introduction of new development projects including the Mahaweli project. Secondly, national defence expenditures increased substantially after 1983. 
When testing either Wagner's Law or Keynesian hypothesis, we obviously examine the relationship between government expenditure and economic growth. Figure 3 illustrates the relationship between growth of the size of government ${ }^{3}$ and economic growth. As displayed Figure 3, there is no clear relationship between the growth of the size of government and economic growth.

Apart from examining the relationship between growth of the size of government and economic growth, this study also examines relationship between size of government (in term of government total expenditure as a percentage of GNP) and economic growth. In general, when a small government fails to focus on and efficiently provide core functions such as protection of persons and property, a legal system, a stable monetary regime, infrastructures, there is no reason to believe that it promotes economic growth. Hence, governments- including those that are small- can be expected to register slow rates of economic growth when these core functions are poorly performed (Gwartney et al 1998). Nevertheless, as illustrated in Figure 4, there is also no clear trade-off between size of government and economic growth in Sri Lanka.

This evidence indicates that size of government is not a driving factor for economic growth. Nevertheless, one cannot ignore the role of government in economic growth for several reasons. First, as noted by Gwartney et al (1998), unless proper adjustment is made for how well the core functions are performed, the empirical relationship between size of government and economic growth is likely to be a loose one. Secondly, different categories of government expenditures might play a different role in economic development. For example, expenditures on health, national education, and infrastructures might probably enhance economic growth, while some recurrent expenditure might slow down economic growth. An in-depth analysis employing such disaggregated data will deepen our understanding of the relationship between government expenditure and economic growth. Such an analysis, indeed, goes beyond the purpose of this current study.

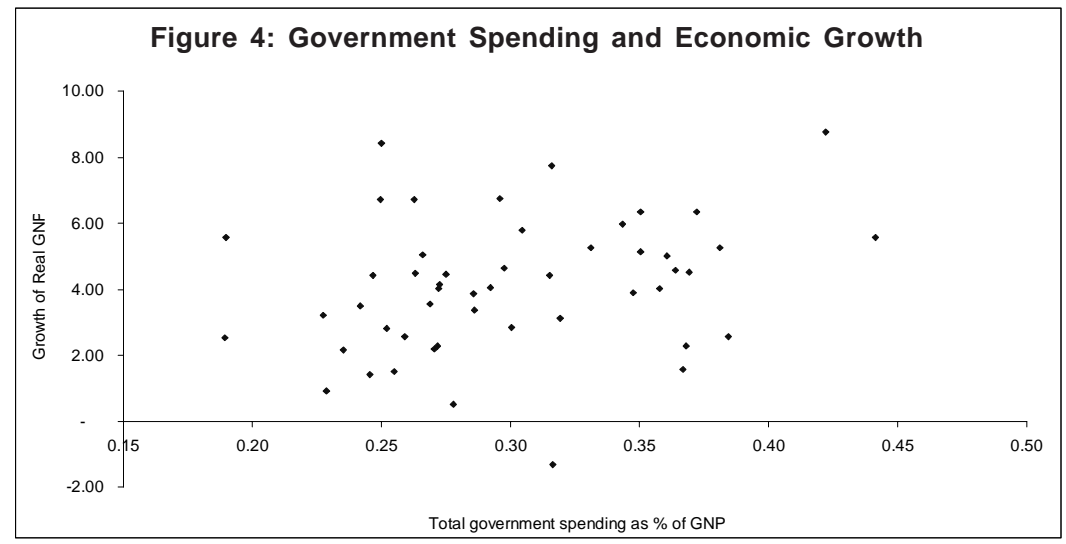

3/ Total government expenditures as a share of GNP are used to measure the size of government. 


\section{Methodology}

\section{A. Test for Cointegration}

Cointegration is a statistical implication of the existence of a long-run relationship between economic variables. The basic idea behind cointegration is that if, in the long-run, two or more variables move closely together, even though the variables themselves are trended, the difference between them is constant. One of the benefits of this approach is that the longrun equilibrium relationship can be modeled by a straightforward regression involving the levels of the variables (Inder 1993). From a statistical point of view, a long-run relationship means that the variables move together over time so that short-run disturbances from the long-run trend will be corrected (Manning and Andrianacos 1993). A lack of cointegration suggests that such variables have no long-run relationship. The standard approach to investigate both the long-run relationship and short-run dynamic between economic variables is the cointegration analysis and its error correction model representation.

There are two alternative techniques for running cointegration tests: the Engle-Granger (1987) two step test and the maximum likelihood method developed by Johansen (1988) and Johansen and Juselius (1990). Less error is involved in the Johansen technique because only one step is involved rather than the two steps required in the Engle-Granger technique.

In the Johansen technique for cointegration, we test for $\mathrm{r}$ (the maximum number of cointegration relationships) using the maximum eigenvalue statistics $\left(\lambda_{\max }\right)$. The statistic is given by

$$
\lambda_{\text {max }}=-\mathrm{T} \log \left(1-\lambda_{\mathrm{r}+1}\right)
$$

\section{B. Stationarity and Unit Root Tests}

Many early works on Wagner's Law ignored the stationary requirement of the variables. The examination of stationarity or non-stationarity in a time series is closely related to the test for unit roots. Unit root tests are important in examining the stationarity of a time series. A number of alternative tests are available for testing whether a series is stationary. Among them, the Dickey-Fuller (DF) and the Augmented Dickey-Fuller (ADF) tests are the most common. The ADF test for unit roots indicates whether an individual series is stationary by running OLS regression.

If the first difference of a non-stationary variable is stationary, that variable is said to be integrated of order one, I(1). If second differences are required to achieve stationary, then the variable is integrated of order two, I(2), and so on. Simple regression should be carried out on variables of the same order of integration. Any time-series analysis should start by checking the order of integration of each variable. If the individual variable is $\mathrm{y}_{\mathrm{t}}$, the general form of ADF test can be written as follows:

$$
\begin{aligned}
& \Delta y_{t}=\alpha y_{t-1}+\sum_{i}^{m} \beta_{i} \Delta y_{t-i}+\delta+\gamma t+\varepsilon_{t} \quad(\text { forlevel) } \\
& \Delta \Delta y_{t}=\alpha \Delta y_{t-1}+\sum_{i}^{m} \beta_{i} \Delta \Delta y_{t-i}+\delta+\gamma t+\varepsilon_{t}(\text { for first diferences })(2)
\end{aligned}
$$


where $m$ is the number of lags and $t$ is time. The value of $m$ should be relatively small in order to save degrees of freedom, but large enough not to allow for the existence of autocorrelation in $\varepsilon_{\mathrm{t}}$. $\varepsilon_{\mathrm{t}}$ represents a sequence of uncorrelated stationary error terms with zero mean and constant variance. Having determined the appropriate value of significance, we test $\mathrm{H}_{\mathrm{o}}: \alpha=0$ versus $\mathrm{H}_{\mathrm{a}}: \alpha<0$. Rejection of $\mathrm{H}_{\mathrm{o}}$ means that $\mathrm{y}_{\mathrm{t}}$ is $\mathrm{I}(0)$ while acceptance implies that it is integrated of order (1).

The theory behind tests for non-stationarity of a series, or the existence of a unit root, is somewhat complicated so we begin our discussion with a cookbook approach to testing for unit roots. It describes the ADF test without going into the underlying theory.

The ADF test consists in running a regression of the first difference of the series against the series lagged once, lagged difference terms, and optionally, a constant and a time trend. There are three choices in running the ADF test regression. One is whether to include a constant term in the regression. Another is whether to include a linear time trend. The third is how many lagged differences are to be included in the regression. In each case the test for a unit root is a test on the coefficient of the lagged dependent variable in the regression. If the coefficient is significantly different from zero the hypothesis that y contains a unit root is rejected and the hypothesis is accepted that $\mathrm{y}$ is stationary rather than integrated.

The output of the ADF test consists of the t-statistic on the coefficient of the lagged test variable and critical values for the test of a zero coefficient. A large negative t-statistic rejects the hypothesis of a unit root and suggests that the series is stationary. Under the null hypothesis of a unit root, the reported t-statistic does not have the standard t- distribution. The reported critical values are chosen on the basis of the number of observations and the estimation option. One may want to re-run the test equation with a different selection of right-hand variables (add or delete constant, trend, or lagged differences).

If the Dickey-Fuller t-statistic is smaller (in absolute value) than the reported critical values, you cannot reject the hypothesis of non-stationarity and the existence of a unit root. You would conclude that your series may not be stationary. One may then wish to test whether the series is I(1) (integrated of order one) or integrated of a higher order. A series is I(1) if its first difference does not contain a unit root. One can repeat the ADF test on the first difference of the series to test the hypothesis of integration of order 1 against higher orders.

One can repeat the test on second differences if the first difference may be non-stationary.

\section{Causality Test}

In economics, systematic testing and determination of causal direction only became possible after an operation framework was developed by Granger (1969) and Sims (1972). Their approach is simply based on the axiom that the past and present may cause the future but the future cannot cause the past (Granger 1980). In econometrics the most widely used operational definition of causality is the Granger definition of causality: '...$X$ is a Granger cause of $\mathrm{Y}$ (denoted as $\mathrm{X} \rightarrow \mathrm{Y}$ ), if present $\mathrm{Y}$ can be predicted with better accuracy by using past values of $X$ rather than by not doing so, other information being identical ...' (Granger, 1980)

In the literature, there are various tests for determining Granger causality in a bivariate system. Among them, the most common method is the ordinary least squares (OLS) version of the Granger test, because its ease of implementation and power. 
There are a number of causality studies in the field of public expenditure and economic growth. However, only a few of them (Ansari et al 1997, Demirbas 1999, Jackson et al 1998, Khundrakpam 2001) have checked for the time series properties of stationary and cointergration of the time series involved.

The methodology of the Granger-causality test can be briefly explained as follows. Suppose we test Granger-causality between two variables such as X and Y

$$
\begin{gathered}
Y_{t}=\sum_{i=1}^{m} \alpha_{i} X_{t-1}+\sum_{i=1}^{m} \beta_{i} Y_{t-i}+u_{1 t} \\
X_{t}=\sum_{i=1}^{m} \lambda_{i} X_{t-1}+\sum_{i=1}^{m} \delta_{i} Y_{t-i}+u_{2 t}
\end{gathered}
$$

where $\mathrm{u}_{1 \mathrm{t}}$ and $\mathrm{u}_{2 \mathrm{t}}$ are serially uncorrelated random disturbances with zero mean. We test to see if $\mathrm{X}$ Granger-causes $\mathrm{Y}$ by using the hypothesis as follows:

$\mathrm{H}_{0}: \alpha_{1}=\alpha_{2}=\alpha_{3}=\ldots \alpha_{\mathrm{m}}=0$ is rejected against the alternative, $\mathrm{H}_{1}: \operatorname{not} \mathrm{H}_{0}$

Similarly, we test if $\mathrm{Y}$ Granger causes $\mathrm{X}$ by testing the hypothesis as follows:

$\mathrm{H}_{0}^{*}: \delta_{1}=\delta_{2}=\delta_{3}=\ldots \delta_{\mathrm{m}}=0$ is rejected against the alternative, $\mathrm{H}_{1}^{*}:$ not $\mathrm{H}_{0}$

If better predictors of a given series $\mathrm{Y}$ can be obtained by adding to lagged values of $\mathrm{Y}$ current and lagged values of another given variable $\mathrm{X}$, then $\mathrm{X}$ is said to Granger-cause $\mathrm{Y}$. Altogether, there are four possible results of Granger-causality:

(1) unidirectional causality from $\mathrm{X}$ to $\mathrm{Y}$ is indicated if the estimated coefficients on lagged $\mathrm{X}$ is (model 3 ) are statistically different from zero as a group $\left(\Sigma \alpha_{i}=0\right)$ and the set of estimated coefficients on the lagged $\mathrm{Y}$ in model 4 is not statistically different from zero $\left(\Sigma \delta_{\mathrm{i}}=0\right)$.

(2) unidirectional causality from $\mathrm{Y}$ to $\mathrm{X}$ exists if the estimated coefficients on lagged $\mathrm{X}$ is (model 3) are not statistically different from zero as a group $\left(\Sigma \alpha_{i}=0\right)$ and the set of the lagged Y estimated coefficients in model 4 is statistically different from zero $\left(\Sigma \delta_{i}=0\right)$.

(3) Feedback or bilateral causality, exits when the sets of $X$ and Y coefficients are statistically significantly different from zero in both regressions.

(4) Independence is identified when the sets of X and Y coefficients are not statistically significant in both the regressions.

It is important to note that temporal precedence does not imply a cause and effect relationship, but establishing the order of temporal precedence between two variables can be very useful to understand the nature of several economic problems. As noted by Park (1998), in number of previous studies of this nature, important statistical properties of the time-series data (for example non-stationary variables) have not been taken into account when the Granger-causality tests were implemented. To avoid the problem of the spurious regression and the failure to account for the appropriate dynamic specification, we first perform unit roots tests on our variables. If the series are non-stationary for the levels of the variables, then we test for their first differences. Doing the unit roots exercise (as explained in section 8.2), we can then proceed with the Granger test using the variable in it stationary 
forms (either levels or their first, or second differences) without incurring in the problem of the spurious regression.

\section{Empirical Results}

This section presents the empirical results found for the data set employed in this study. Sub-section 8.1 presents unit root test results while sub-section 8.2 analyzes cointegration test results. Sub-section 8.3 presents Granger causality test results.

\section{A. Unit Root Tests Results}

First, we investigate the stationary properties of the data using the ADF test. The ADF test is widely regarded as one of the most efficient test for integration level.

Table 1 presents the calculated t-value from ADF tests on each variable in levels and in first differences. In the case of the levels of the series, the null-hypothesis of non-stationarity cannot be rejected for any of the series. This is true in the case of both the logarithmic and non-logarithmic transformations. Therefore, the levels of all series are non-stationary, but it is rejected with first differences, which suggests that these variables are I(1). The results in table 1 are consistent with those of prior studies that have done for other countries.

Table 1 - ADF Unit Root Test in Level

\begin{tabular}{lllll}
\hline Variable & \multicolumn{2}{c}{ Level } & \multicolumn{2}{c}{ First Difference } \\
\hline & $(1)$ & $(2)$ & $(1)$ & $(2)$ \\
\hline LGNP & 0.454 & -2.98 & $-3.69^{*}$ & $-3.87^{* *}$ \\
& $(2)$ & $(2)$ & $(2)$ & $(2)$ \\
\hline LTE & -1.27 & -1.99 & $-5.31^{*}$ & $-5.45^{*}$ \\
& $(2)$ & $(2)$ & $(2)$ & $(2)$ \\
\hline LCE & -0.92 & -3.20 & $-5.86^{*}$ & $-5.86^{*}$ \\
& $(2)$ & $(2)$ & $(2)$ & $(2)$ \\
\hline LGNPN & 1.37 & -2.39 & $-2.63^{* * *}$ & -2.65 \\
& $(4)$ & $(4)$ & $(4)$ & $(4)$ \\
\hline LTEN & -0.86 & -2.31 & $-5.43^{*}$ & $-5.38^{*}$ \\
& $(2)$ & $(2)$ & $(4)$ & $(4)$ \\
\hline LTEGNP & -2.23 & -1.83 & $-5.34^{*}$ & $-5.73^{*}$ \\
& $(2$ & $(2)$ & $(2)$ & $(2)$ \\
\hline $1 \%$ CV & -3.5713 & -4.1584 & -3.5745 & -4.1630 \\
$5 \%$ CV & -2.9228 & -3.5145 & -2.9241 & -3.5066 \\
$10 \%$ CV & -2.5990 & -3.3370 & -2.5997 & -3.3424 \\
\hline
\end{tabular}

NOTES: ADF test statistics were computed using regressions with (1) an Intercept, and (2) an Intercept and a Trend. The tests were also performed using maximum lag length of 4, and from this maximum the appropriate lag length for each of the variable was chosen based on the Akaike Information criteria (AIC). Mackinnon (1991) critical values are used for rejection of hypothesis of a unit root. * $1 \%$, ** $5 \%$, *** $10 \%$ 
The results for unit root tests show that all of the series are integrated of order one [I(1)], and become stationary after differencing once. Since all of the series are integrated of the same order, the series may be tested for the existence of a long-run relationship between them, that is a cointegrating relationship.

\section{B. Cointegration Test Results}

To perform a cointegration test, it is necessary that the order of integration of all the variables in the long-run relationship be the same (Enders 1995). The order of integration can be defined as the number of time a time series variable must be differenced for it to become stationary. From the ADF tests above (Table 1), all the variables are integrated of order one, i.e. I (1) because the first difference of these variables is stationary.

Table 2 reports the results of Johansen's maximum Eigenvalue test $\left(\lambda_{\max }\right)$. This test is applied to the six versions of the Wagner's Law. AIC criterion was used in determining the appropriate lag lengths. Accordingly, optimal lag length of two was sufficient to make the residuals uncorrelated and homoskedastic. As presented in Table 2, the results did not reject the null hypothesis of no-cointegration. Therefore, on the basis of the results, the long-run relationship between government and real GNP is not found by using the maximum likelihood approach. This confirms earlier findings but without evidence of causality, nothing can be said whether models attributed to Wagner or Keynes are valid.

Table 2 - Johansen Cointegration Test Results

\begin{tabular}{lcccl}
\hline Variables & \multicolumn{2}{c}{$\Lambda_{\text {max }}$} & Lags & Cointegration Equation \\
& $\mathbf{r}=\mathbf{0}$ & $\mathbf{r = 1}$ & & \\
\hline LTE, LGNP & 8.9219 & 0.2119 & 2 & LTE $=3.2323+1.0762 \mathrm{LGNP}$ \\
LCE, LGNP & 13.9175 & 0.0423 & 2 & LCE $=0.1646+1.1729 \mathrm{LGNP}$ \\
LTE, GNPN & 13.4647 & 0.1978 & 2 & LTE $=12.791+1.2419 \mathrm{GNPN}$ \\
L(TE/GNP), LGNPN & 11.9496 & 0.0706 & 2 & L(TE/GNP) $=0.002-0.1213 \mathrm{LGNPN}$ \\
LTEN, LGNPN & 11.9496 & 0.0706 & 2 & LTEN $=0.002+0.8787 \mathrm{LGNPN}$ \\
L(TE/GNP), LGNP & 8.9219 & 0.2119 & 2 & L(TE/GNP) $=3.232+0.0762 \mathrm{LGNP}$ \\
\hline
\end{tabular}

The 5\% critical values are bigger than the calculated values. So the results fail to reject the null hypothesis of no long-run relationship.

Furthermore we have to treat these results with caution because the findings of noncointegration do not exclude the possibility of cointegratin in some disaggregated data such as government expenditures on education, health, military etc.

However, without evidence of cointegration an error correction procedure to model short-run dynamics cannot be used. Nevertheless, it is possible to continue to model the short-run dynamics by applying Granger causality test to measure for possible causal relationships between variables (Ansari et al 1997). Although in the absence of a long-run relationship between variables, it still remains of interest to examine the short-run linkages between them, i.e. causality test. In the following section, the study will apply with the Granger causality test. 


\section{Granger Causality Test Results}

The Granger causality test results presented in Table 3 include the six versions of Wagner's Law. In the tests, causality is hypothesized to run from GNP (or GNP/P) to the dependent variable, which takes four different forms: TE, CE, TE/GNP, TE/N (see the six versions of Wagner's Laws, section 4). In other words, the Wagner's hypothesis that GNP causes public expenditure requires that public expenditure does not cause GNP. The tests are carried out using the first difference of each series since the series become stationary at the first differences.

AIC was used to determine optimum lag lengths. Results are presented for four different chosen lag lengths- 1, 2, 3 and 4 lags (see table 3 ). The null hypothesis of non-causality is tested using F-statistics. The results in Table 3 indicate that there is no evidence to support either Wagner's Law in any of its versions or Keynesian hypothesis. Though the null hypothesis of non-causality is not statistically significance, the results predict the short-run nature of the Keynesian hypothesis. However, as Ansari et al (1997) argued, many factors can lessen the causal relationship between the two macro variable, i.e. GNP and public expenditure. Expenditure on health, education, infrastructure facilities can do much to encourage growth and development in the economy.

\section{Table 3 - Results of Granger Causality Tests of the Six Versions of Wagner's Law}

\begin{tabular}{|c|c|c|c|c|c|}
\hline \multirow{2}{*}{$\begin{array}{l}\text { Versions of } \\
\text { Wagner's } \\
\text { Law }\end{array}$} & \multirow{2}{*}{ Null Hypothesis } & \multicolumn{4}{|c|}{$P$ value of F-statistic } \\
\hline & & 1 lags & 2 lags & 3 lags & 4 lags \\
\hline \multirow[t]{2}{*}{1} & GNP does not cause & 0.122 & 0.403 & 0.193 & 0.253 \\
\hline & TETE does not cause GNP & 0.241 & 0.427 & 0.439 & 0.754 \\
\hline \multirow[t]{2}{*}{2} & GNP does not cause & 0.888 & 0.641 & 0.728 & 0.798 \\
\hline & CECE does not cause GNP & 0.279 & 0.442 & 0.529 & 0.728 \\
\hline \multirow[t]{2}{*}{3} & GNP/N does not cause & 0.294 & 0.719 & 0.245 & 0.289 \\
\hline & TETE does not cause GNP/N & 0.288 & 0.432 & 0.428 & 0.842 \\
\hline \multirow[t]{2}{*}{4} & GNP/N does not cause & 0.644 & 0.926 & 0.325 & 0.396 \\
\hline & TE/GNPTE/GNP does not cause GNP/N & 0.351 & 0.478 & 0.389 & 0.863 \\
\hline \multirow[t]{2}{*}{5} & GNP/N does not cause & 0.185 & 0.572 & 0.93 & 0.334 \\
\hline & TE/NTE/N does not cause GNP/N & 0.351 & 0.478 & 0.389 & 0.862 \\
\hline \multirow[t]{2}{*}{6} & GNP does not cause & 0.320 & 0.772 & 0.386 & 0.417 \\
\hline & TE/GNPTE/GNP does not cause GNP & 0.241 & 0.427 & 0.439 & 0.754 \\
\hline
\end{tabular}




\section{Conclusion}

The paper investigates the existence of a long-run relationship between public expenditure and GNP using data for Sri Lanka during 1952-2002. Evidence of cointegration is only sufficient to establish a long-run relationship between public expenditure and income as suggested by Wagner(1883). However, to support Wagner's law it would require unidirectional causality from income to public expenditure. Therefore, cointegration should be seen as a necessary condition for Wagner's law, but not sufficient. Hence, conditional on cointegration results, it is necessary to look at the causality properties of the models. Using the Granger causality test and Sri Lankan time series aggregate data, the study found no empirical support either for the Wagner's Law or the Keynesian hypothesis.

First, we looked at the time series properties of the data, i.e. the existence of unit roots. The study found that both the government expenditure and GNP variables were non-stationary in levels, but stationary in first differences. Accordingly, the data are integrated of order one $[\mathrm{I}(1)]$. Then we apply the cointegration test to six versions of Wagner's Law. According to the results, there is no cointegrating relationship between the government expenditure and national income. Inclusion of time trends into cointegration regressions did not change the results. Accordingly, we could not find a long-run relationship between government expenditure and GNP for any of the six versions of Wagner's Law.

According to empirical findings of this study, one may tentatively suggest that the growth of public expenditure in Sri Lanka is not directly dependent on and determined by economic growth as Wagner's Law indicates. Public expenditure is the outcome of many decisions in the light of changing economic circumstances. It is shaped by decisions about how public expenditure should be distributed among competing groups; for example whether geographically concentrated or aggregated in organized interests. The core functions of the government are also vitally important. Therefore, pressure groups and interest group behavior, political processes etc. may be considered as possible explanatory variables for the increase in the size of government expenditure.

In addition, it is also possible to examine disaggregated data to investigate government expenditure and economic growth in terms of Wagner's Law, as Barro (1990) suggested, since the impact of government spending may vary depending on the component of government expenditure. For example, Devarajan et al (1993 and 1996), using a sample of 14 OECD countries, found that spending on health, transport and communication have positive impacts (spending on education and defence did not have a positive impact). In the majority of studies, total government spending appears to have a negative effect on growth (Alexander 1990, Folster and Henrekson 1999). 


\section{References}

Abizadeh, S., and Gray, J. (1985), “Wagner's Law: A Pooled Time-series, Cross-Section Comparison", National Tax Journal, Vol. 38 (2): 209-218

Agell, J., Lindh, T., and Ohlsson, H. (1997), “Growth and the public sector: a reply”, European Journal of Political Economy, Vol. 15 (2), 359-366.

Alexander, W.R. (1990), “Growth: Some Combined Cross-sectional and Time Series”, Applied Economics, Vol. 22, 1197-1204.

Al-Faris, A.F. (2002), "Public Expenditure and Economic Growth in the Gulf Cooperation Council Countries", Applied Economics, Vol. 34 (9): 1187-1193.

Ansari, M.I. Gordon, D.V., and Akuamoah, C. (1997), "Keynes Versus Wagner: Public Expenditure and National Income for Three African Countries", Applied Economics, Vol. 29: 543-550.

Barro, R.J. (1990), “Government Spending in a Simple Model of Endogenous Growth", Journal of Political Economy, Vol. 98 (3): 103-125.

Beck, M. (1982), “Towards a Theory of Public Sector Growth”, Public Finance Vol. 37.

Bird, R.M. (1971), “Wagner's Law of Expanding State Activity”, Public Finance Vol. 26.

Chen, D.Y,. Tseng, T. Wu, T., and Chang, W. (2003), “The Relationship between Public expenditure and Economic Growth - An International Comparative Study", National Chiao Tung University, Taiwan.

Cheng, B.S., and Lai. T.W. (1997), "Government Expenditure and Economic Growth in South Korea: A VAR Approach”, Journal of Economic Development, Vol. 22 (1).

Couraakis, A.S., Moura-Roque, F. and Tridimas, G. (1993), "Public Expenditure Growth in Greece and Portugal: Wagner's Law and Beyond", Applied Economics, Vol. 25 (1) 125- 134.

Demirbas, S. (1999), “Co integration Analysis- Causality Testing and Wagner's Law: The case of Turkey”, 1950 -1990,

Devarajan, S., S. Vinaya and H. Zou (1993), "What do Governments Buy? The Composition of Public Spending and Economic Performance", Policy Research, Working Paper WPS 1082, Washington, DC: The World Bank.

Devarajan, S., S. Vinaya and H. Zou (1996), "The Composition of Public Expenditures and Economic Growth”, Journal of Monetary Economics, 37: 313-344.

Engle, R. and Granger, C. W. J., (1987), “Co integration and Error Correction: Representation, Estimation and Testing”, Econometrica, 251- 276.

Folster, S. and M. Henrekson (1999), "Growth and the public sector: a critique of the European”, Journal of Political Economy, 15: 2,337-358. 
Ghali, K.H. (1997), “Government Spending and Economic Growth in Saudi Arabia”, Journal of Economic Development, Vol. 22 (2)

Goffman, I.J. (1968), “On the Empirical Testing of Wagner’s Law: A Technical Note”, Public Finance, Vol. 23 (3): 359-64

Granger, C.W. (1980), “Testing for Causality”, Journal of Economic Dynamics and Control, Vol. (2): 329-352

., (1969), "Investigating Causal Relations by Econometric Models and Cross-Spectral Methods" Econometrica, Vol. 37 (3): 422-438

Granger, C.W.J., and Newbold, P. (1974), "Spurious Regression in Econometrics”, Journal of Econometrics, Vol. 39 (1-2): 111-120

Gwartney, J., Lawson, R., and Holcombe, R., (1998), “The Size and Functions of Government and Economic Growth", a paper prepared for the Joint Economic Committee (JEC), Jim Saxton, Chairman, Washington, USA, http://www.house.gove/jec/.

Gyles, A.F. (1991), “A Time-Domain Transfer Function Model of Wagner's Law: The Case of the United Kingdom Economy”, Applied Economics, Vol. 23 (2): 327- 330.

Hansson, P.,and M. Henrekson (1994), “A New Framework for Testing the Effect of Government Spending on Growth and Productivity”, Public Choice, Vol 81:381401.

Henrekson, M. (1993), “Wagner's Law- A Spurious Relationship?”, Public Finance, Vol. 48 (2): 406-415.

Hondroyiannis, G., and Papapetrou, E. (1995), “An Examination of Wagner's Law for Greece: An Cointegration Analysis”, Public Finance, Vol. 50 (1): 67- 79.

Inder, B. (1993), "Estimating Long-run Relationships in Economics: A Comparison of Different Approaches", Journal of Econometric, Vol. 57: 53-68.

Jackson P.M. (1998), “Co integration, Causality and Wagner's Law: A test for Northern Cyprus", 1977-1996, University of Leicester, Discussion paper in Public Economics $99 / 2$.

Johansen, S., (1988), "Statistical Analysis of Co integrating Vectors", Journal of Economic Dynamics and Control, 231- 254.

Johansen, S., and Juselius, K., (1990), "Maximum Likelihood Estimation and Inference on Co integration with Applications to the Demand for Money", Oxford Bulletin of Statistics, 169-210.

Khan, A.H., (1990), "Wagner's Law and the Developing Economy: A Time Series Evidence from Pakistan”, The Indian Economic Journal Vol. 38 (1): 115-123.

Khundrakpam, J. K., (2001), "Public Sector Spending and Economic Growth in India", Occasional Papers, Reserve Bank of India. 
Kneller, R., M. Bleaney and N. Gemmel (1998), "Growth, Public Policy and the Government Budget Constraint: Evidence from OECD Countries", Discussion Papers in Economics 98/14, University of Nottingham.

Lin, S. (1994), “Government Spending and Economic Growth”, Applied Economics, Vol. 26: 83-94.

Mann, A. J. (1980), "Wagner's Law: An Econometric Test for Mexico 1925- 1976", National Tax Journal, Vol. 33 (2): 189- 201.

Manning, L. M., and Adriacanos, D. (1993), "Dollar Movements and Inflation: a Co integration Analysis", Applied Economics, Vol: 25. 1483-1488

Mukherjee. C., White, H., and Wuyts, M., (1998), "Econometrics and Data Analysis for Developing Countries", Routledge, London

Murthy, V.N.R., (1993), “Further Evidence of Wagner's Law fro Mexico: An Application of Co integration Analysis”, Public Finance, Vol. 48 (1): 92-96.

Peacock, A.T., and Wiseman, J. (1979), “Approaches to the Analysis of Government Expenditure Growth", Public Finance Quarterly, Vol. 7

Pryor, F.L. (1968), "Public Expenditures in Communist and Capitalist Nations”, London: George Aallen and Unwin.

Ram, R. (1986), "Causality between Income and Government Expenditure: A Broad International Perspective", Public Finance, Vol. 31 (3) 393-413

Ram, R. (1986), "Government Size and Economic Growth: A new Framework and some Empirical Evidence from Cross-section and Time Series Data", American Economic Review, Vol: 76, 191-203.

Sahni, B.S., and Singh, B. (1984), "On the Causal Directions between National Income and Government Expenditure in Canada", Public Finance, Vol. 39 (3): 359-393.

Sims, C. (1972), “Money, Income and Causality”, American Economic Review, Vol. 62: 540552.

Singh, B., and Sahni. B.S. (1984), "Causality between Public Expenditure and National Income”, Review of Economics and Statistics, Vol. 66 (4): 630-643.

Wagner, A. (1883), "Three Extracts on Public Finance” in R. A. Musgrave and A. T. Peacock (eds) (1958), Classics in the theory of Public Finance. London: Macmillan 